\title{
A sensitivity study of factors influencing warm/thin permafrost in the Swiss Alps
}

\author{
Martina LUETSCHG, ${ }^{1}$ Michael LEHNING, ${ }^{1}$ Wilfried HAEBERLI ${ }^{2}$ \\ ${ }^{1}$ WSL, Swiss Federal Institute for Snow and Avalanche Research SLF, Flüelastrasse 11, CH-7260 Davos-Dorf, Switzerland \\ E-mail: luetschgm@cf.ac.uk \\ ${ }^{2}$ Department of Geography, Glaciology, Geomorphodynamics and Geochronology, University of Zürich-Irchel, \\ Winterthurerestrasse 190, CH-8057 Zürich, Switzerland
}

\begin{abstract}
Alpine permafrost distribution is controlled by a great number of climatic, topographic and soil-specific factors, including snow cover, which plays a major role. In this study, a one-dimensional finite-element numerical model was developed to analyze the influence of individual snow-specific and climatic factors on the ground thermal regime. The results indicate that the most important factor is snow depth. Snow depths below the threshold value of $0.6 \mathrm{~m}$ lack sufficient insulation to prevent low atmospheric temperatures from cooling the soil. The date of first winter snow insulation and variations in mean annual air temperature (MAAT) are also shown to be important. Delays in early-winter snow insulation and in summer snow disappearance are shown to be of approximately equal significance to the ground thermal conditions. Numerical modelling also indicates that the duration of effective thermal resistance of snow cover governs the slope of the linear dependency between MAAT and mean annual ground surface temperatures (MAGST). Consequently, the most direct effect of a long-term rise in air temperatures on ground temperatures is predicted under a thin snow cover with early snowmelt in spring and/or where a large change in the date of total snowmelt occurs, in response to atmospheric warming.
\end{abstract}

\section{INTRODUCTION}

Permafrost in the European Alps is expected to occur on north-facing slopes at altitudes above $2600 \mathrm{~m}$, on southfacing slopes above $3000 \mathrm{~m}$, and in footslope zones with long-lasting avalanche snow at altitudes several hundred metres lower than these (Haeberli, 1975). In contrast to highlatitude lowlands, mid-latitude mountain permafrost regions are characterized by thick and variable snow cover, sparse vegetation, coarse well-drained ground surface materials and complex topography. The ground is generally snow-covered for three-quarters of the year, which strongly affects ground temperatures and permafrost distribution. The snow cover shows marked year-to-year variations in depth, date of first snow and date of total snowmelt (e.g. Beniston, 1997; Zhang and others, 1997; Etzelmüller and others, 2001; Laternser and Schneebeli, 2003).

In addition to locally variable weather, spatial variation in snow depth and density also results from topographic effects, snow avalanches and wind drift. The main thermal influences of a winter snow cover can be attributed to: (1) low thermal conductivity, depending on snow density and snow microstructure (Fierz and Lehning, 2001); (2) high surface albedo; and (3) the energy sink provided by latent heat of fusion during snowmelt (Mellor, 1977; Sturm and others, 1997; Zhang, 2005). The thermal resistance of the snow cover increases with increasing snow depth. From field investigations, a snow depth more than $0.6-0.8 \mathrm{~m}$ was found to be effective in thermally insulating the ground from the atmosphere (Haeberli, 1973; Keller and Gubler, 1993; Hanson and Hoelzle, 2004). Modification of ground temperatures by snow due to higher albedo, thermo-insulation and latent-heat effects occurs during different periods of the winter, and the duration of these periods can have a considerable influence on mean annual ground temperatures
(Goodrich, 1982; Harris and Corte, 1992; Keller, 1994; Seppälä, 1994; Zhang and others, 1996; Zhang, 2005).

For an improved understanding of permafrost distribution and development under the influence of snow-cover variations and/or changing climatic conditions, the effect of different snow parameters on ground temperatures needs to be quantified. As the ground thermal effect of one single changing parameter is difficult to quantify in the field, a number of numerical approaches have been developed to simulate the mass and energy exchange between atmosphere, snow cover and soil. Most of these models have been validated for investigations under high-latitude arctic soil and snow conditions which, compared to the mid-latitude mountain regions, generally show thinner snow cover, finer ground material and fewer topographical variations.

Numerical models of snow-permafrost interactions in high-latitude arctic regions have therefore placed less emphasis on temporal and spatial variation in snow conditions. For example, the one-dimensional (1-D) finitedifference heat-flow with phase-change model, developed by Goodrich (1982), incorporates the thermal effect of a simple snow cover, and includes a single-layer soil with distinct frozen and unfrozen thermal properties. Using the same model, Zhang and Stamnes (1998) concluded that in high-latitude permafrost, ground temperatures were most strongly affected by air temperatures, though soil moisture and snow cover were significant variables. Depth-hoar formation and, hence, changes in effective thermal conductivity and diffusivity in a thin arctic seasonal snow cover and the effect on the ground thermal regime were investigated in detail in a sensitivity study based on the same model (Zhang and others, 1996).

Smith and Riseborough (1996) presented a functional model of the permafrost-climate relationship, including geographical variations of climatic, surface and soil factors, 
and considered the seasonal thermal influence of snow and vegetation cover. The onset date of the snow cover and the snow thickness were shown to be critical factors for the persistence of marginal permafrost occurrence in highlatitude lowlands (Zhang and others, 2001). An energybalance approach, based on a one-dimensional heat-transfer model, was used by Ling and Zhang $(2003,2004,2006)$ to demonstrate the sensitivity of near-surface ground temperatures in the Alaskan Arctic to the timing and duration of a seasonal snow cover, the presence of unfrozen water and variations in snow density.

Romanovsky and others (1997) compared three numerical thermal models, which employ different numerical methods and use different implementations of freezing and thawing processes to generate analytical solutions to predict the effects of air-temperature changes. Best agreement between the models was shown for the Neumann solution, and most significant differences occurred for simulations with large time and depth steps and with field data such as surface boundary conditions. The accuracy of heat-flux models therefore appears to depend on the choice of the time and depth steps, the analytical treatment and appropriate model calibration.

Generally, existing arctic 1-D snow-permafrost modelling approaches include complex hydrothermal processes of the freezing and thawing of the fine-grained water-rich active layer, while accounting for the thermal influences of a seasonal snow cover in a simplified way. However, the highalpine permafrost environment is dominated by a spatially and temporally highly variable and thicker snow cover, more complex topography and coarser, poorly vegetated soil material. Consequently, and in contrast to the existing arctic snow-permafrost interaction models, modelling approaches to the alpine environment need to emphasize the simulation of strong seasonal variation of the snow cover, and include simplified hydrothermal processes appropriate to coarsergrained, well-drained and drier soil materials. For this reason, an alpine permafrost-snow interaction model was developed by extending an existing and validated snow model to incorporate its thermal effect on the underlying soil. The model is based on a Lagrangian finite-element scheme simulating the local snow cover from measured meteorological data input (Lehning and others, 1999; Bartelt and Lehning, 2002).

In the present study, which is based on this model, the effects of changing snow depth, date of first snow, date of total snowmelt and changing air temperature on the ground thermal regime were investigated separately for the first time under the snow and soil conditions of the high-alpine permafrost environment. Finally, the evolution of the seasonal snow cover and the resulting changes in mean annual ground temperatures anticipated under a warming climate are discussed with respect to different topographical situations in the Alps.

\section{NUMERICAL MODEL}

The 1-D numerical model, SNOWPACK, allows simulation of local snow cover using data from high-alpine automatic weather and snow stations (Lehning and others, 1999; Bartelt and Lehning, 2002). This model is based on a Lagrangian finite-element scheme, and the snow cover is regarded as a three-component material consisting of air, water and ice. The processes of snow settlement, transport of heat, water vapour and liquid water in the snow cover, metamorphism of the snow crystals, phase-change processes and the exchange of mass and energy between the snow and the atmosphere are taken into account (Fierz and Lehning, 2001; Lehning and others, 2002a, b).

For the purpose of this sensitivity study, the SNOWPACK numerical grid was extended to include soil layers. The soil is simulated as a four-component material consisting of air, water, ice and soil mineral components. Soil-specific characteristics, such as water retention depending on grain size and thermal conductivity depending on water and ice content, were implemented (Lütschg, 2005). In the soil part of the model, mass and energy transport and phase-change processes were taken into account in the same way as in the snow layers, and the same simple bucket water-transport algorithm was applied. This represents an approximation of the hydrological processes within the soil layers. However, since the model allows for the definition of an arbitrary number of layers in the soil, a realistic simulation of water transport, including meltwater infiltration from above, can be obtained. In general, the infiltration is more realistic if a higher number of thinner layers is chosen. For our simulation we used a total of 42 soil layers with thicknesses increasing from $0.17 \mathrm{~m}$ at the surface to $0.5 \mathrm{~m}$ at the bottom of the domain. The soil component of the model was validated with laboratory measurements of temperature evolution in different soil textures and has proved to be a valuable instrument for simulations of the ground thermal regime (Lütschg, 2005).

Simulations with the extended SNOWPACK model require the following data input: (1) a meteorological input derived from measurements of a network of high-alpine snow and weather stations (Lehning and others, 1999) and (2) soil initial conditions such as temperature and volumetric contents of the four soil components (soil, water, ice and voids), grain size of the soil layers, thermal properties (thermal conductivity and specific heat) and density of the soil fraction. Different soil types are characterized in the model by the mean grain-size values, which control water-retention capability and effective conductivity (Lütschg, 2005).

Two different meteorological data records from the same site were applied in the simulations presented here, both representing permafrost conditions but showing different snow-depth scenarios. The data records are based on the measurements from the years 1992/93 and 1993/94 at the automatic snow and weather station at Weissfluhjoch (2540 ma.s.l.), eastern Swiss Alps, which is located in a flat non-permafrost area. Both data records were modified in the same way to generate data equivalent to a highelevation/north-facing location. The measured air temperatures were extrapolated to an altitude of $3000 \mathrm{~m}$, using the standard adiabatic lapse rate of $0.6^{\circ} \mathrm{C}(100 \mathrm{~m})^{-1}$, and the shortwave incoming radiation was transformed to the equivalent radiation on a $30^{\circ}$ north-facing slope. Snow depth can show strong variation with topography. At exposed locations, such as close to a mountain ridge, strong winds accompanying snowfall events can cause snow deposition only on the lee side, or windward-side snow erosion and leeward-side snow accumulation (Lehning and others, 2008). In a snowdrift experimental site on a mountain ridge in the eastern Swiss Alps, new-snow depths were observed to be only half of the new-snow depths measured at the flat reference site. Due to wind erosion, parts of the windward side of the mountain ridge showed no 


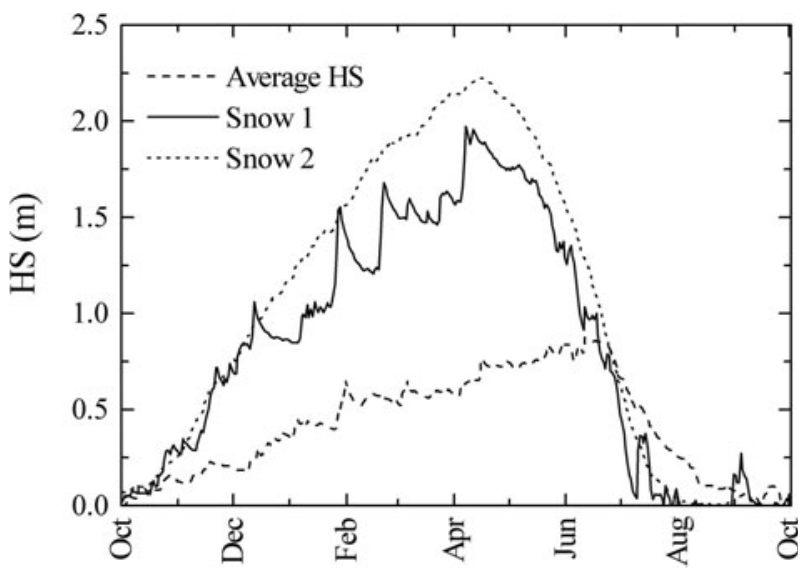

Fig. 1. Comparison of the snow-cover scenarios applied for the simulations with the long-term average snow-depth evolution from Weissfluhjoch (2540 m a.s.l.): Snow 1 scenario, based on the modified data record of Weissfluhjoch during 1992/93, corresponds well to the average snow-depth evolution (average $\mathrm{HS}$ ), whereas Snow 2 scenario, based on the modified data record of Weissfluhjoch during 1993/94, represents an extremely thin but long-lasting snow cover.

new snow accumulation or even erosion of the older snow layers (Gauer, 1999; Lehning and others, 2008).

In the input data of the present study, the effects of such topographically influenced snow erosion on total snow depth were approximated. During periods of heavy snowfall in November to February, the new snow accumulation in the input data for 1992/93 was reduced by a factor of 0.7 and for $1993 / 94$ by a factor of 0.3 , to account for two different topographical positions subject to low and high wind erosion respectively (e.g. Gauer, 1999). With this modification, two meteorological data records were created, both of which allow for permafrost simulations but which show different snow-depth evolution (Snow 1 and Snow 2), shown in Figure 1. The snow depth based on the 1992/93 data record corresponds well to the long-term mean snow depth for the location of Weissfluhjoch (scenario: Snow 1), and the second snow-depth scenario, based on the 1993/94 meteorological data record, represents an extremely thin and long-lasting snow cover (scenario: Snow 2). In general, individual meteorological parameters cannot be changed independently for the purpose of climate scenario simulations. However, consistent sets of forcing parameters need to be assumed, and it appears justifiable to adjust precipitation to take account of snow erosion by wind, and to adjust air temperature to account for higher altitude. These changes appear to be sufficiently independent of other changes such as humidity or longwave radiation.

The initial soil conditions were defined as $16 \mathrm{~m}$ frozen soil, consisting of a coarse gravelly surface layer (retaining up to $2 \%$ water) with layers of sandy to gravelly soil underneath (water retention up to 13\%). All simulations were performed with measured incoming shortwave and longwave radiation at the surface. Permafrost conditions were chosen to be close to the melting point by defining the lower temperature boundary condition (i.e. temperatures at $16 \mathrm{~m}$ depth) to be $-0.5^{\circ} \mathrm{C}$ throughout the simulations. A constant thermal lower boundary is a first approximation and was chosen, as the present sensitivity study focuses on short-term interannual variations only, in order to provide first insights into
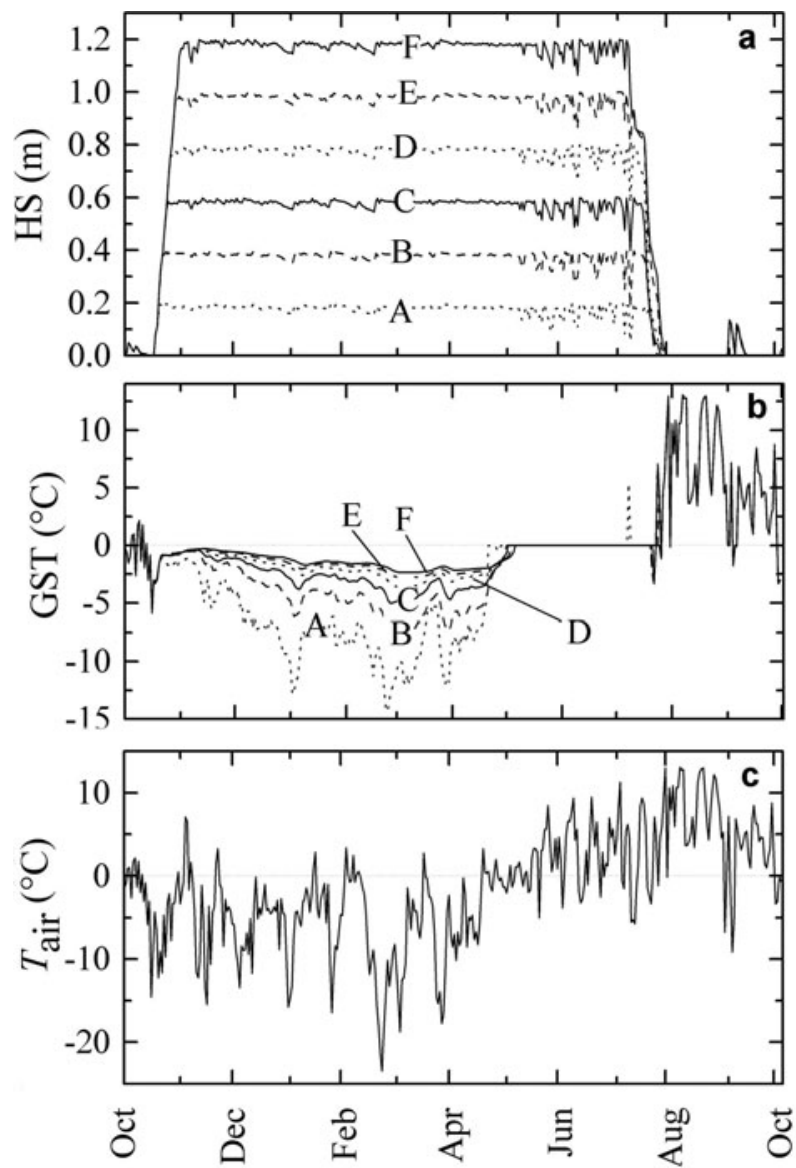

Fig. 2. (a, b) Simulated snow scenarios of (a) different snow depths $(\mathrm{HS})$ and $(\mathrm{b})$ the resulting ground snow temperatures (GST). With increasing total snow depths of (A) $0.2 \mathrm{~m}$, (B) $0.4 \mathrm{~m}$, (C) $0.6 \mathrm{~m}$, (D) $0.8 \mathrm{~m}$, (E) $1 \mathrm{~m}$ and (F) $1.2 \mathrm{~m}$, GST show decreasing short-term fluctuations. (c) Air temperature $\left(T_{\text {air }}\right)$ remained unchanged.

corresponding sensitivities and governing factors. Snowdepth evolution is simulated by providing either total snow depth (for the simulation of different snow depths, dates of first snow and total snowmelt) or new-snow equivalents (for the simulations of the temperature effect). The choice of the initial conditions strongly affects the first year of a simulation run. A model spin-run time of 4 years was applied after which the transient effects were observed to have decayed in the uppermost $10 \mathrm{~m}$ of soil and the temperatures in these layers were considered to be close to equilibrium. Most simulations presented in this study were based on the modified meteorological input of 1992/93 (Snow 1). Additional simulations using the modified meteorological data input of 1993/94 (Snow 2) from a significantly thinner snow cover were run for comparison within the study on the ground thermal effect of changing air temperatures.

\section{RESULTS}

In the present sensitivity study, model simulations were carried out to develop a better understanding of the ground thermal influence of one changing factor at a time. Increasing snow depths involve an increase in thermal resistance, and when snow depths exceeded a certain depth the underlying ground was fully thermally decoupled from the cold winter atmosphere. Figure $2 \mathrm{a}$ and $\mathrm{b}$ show the simulation results of 

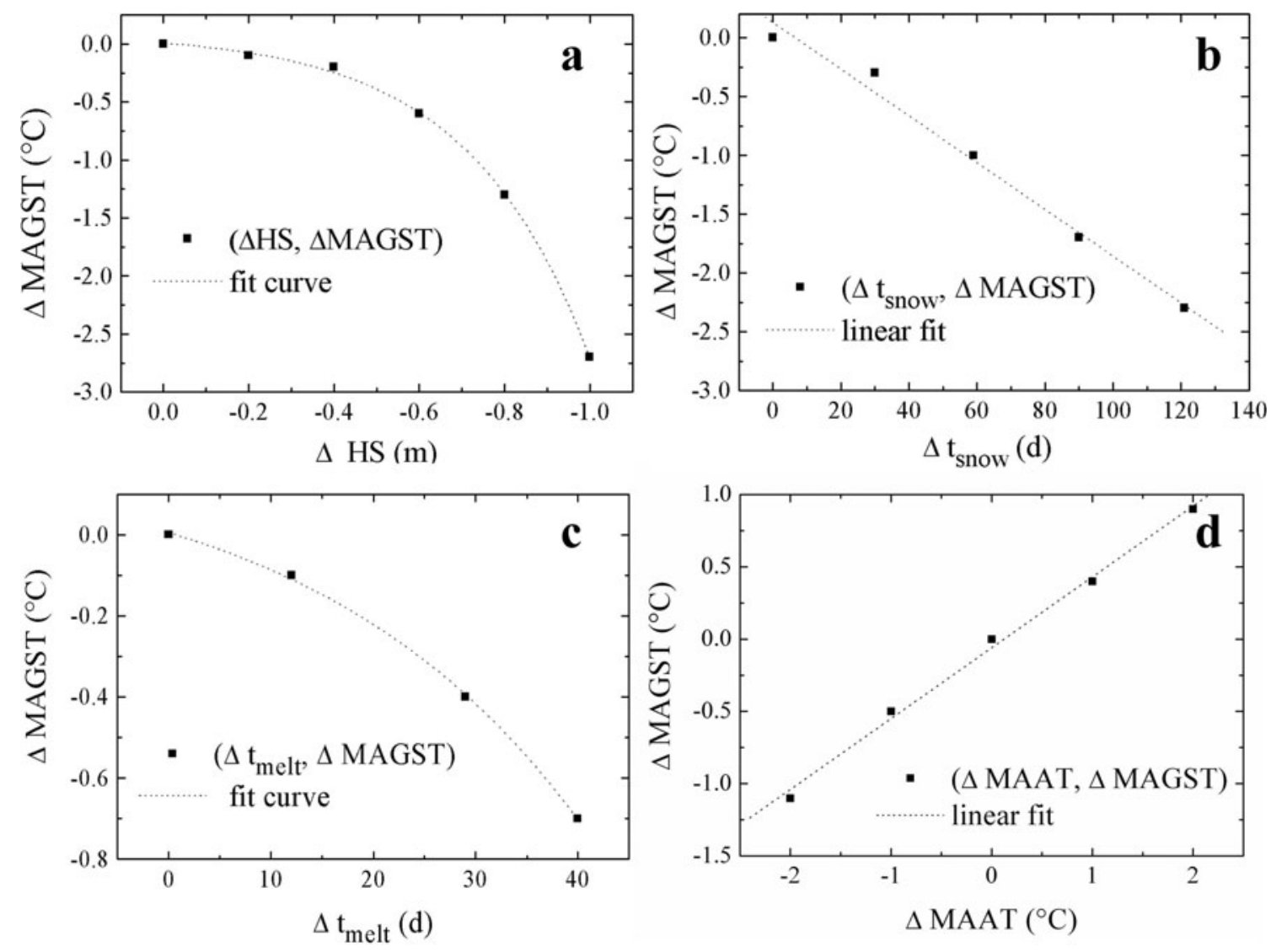

Fig. 3. Correlation results of the effect of different changing permafrost-relevant factors on the change in mean annual ground surface temperatures $(\triangle \mathrm{M} A G S T)$, showing (a) the non-linear influence of changes in snow depth $(\Delta \mathrm{HS})$; (b) the linear impact of the delay in first snow insulation in early winter $\left(\Delta t_{\text {snow }}\right)$; (c) the non-linear influence of the delay in total snowmelt in summer $\left(\Delta t_{\text {melt }}\right)$; and (d) the linear influence of changes in mean annual air temperatures $(\Delta \mathrm{MAAT})$. Regression equations are listed in Table 1.

the effect of changes in total snow depth on ground surface temperatures (GST), demonstrating that with increasing total snow depth (a), the GST (b) increase. The GST curves directly reflect the diurnal air-temperature fluctuations (Fig. 2c) under a thin snow cover. These ground temperature fluctuations decline with increasing snow depths, due to increasing thermal resistance of the snowpack. A snow depth of $0.6-0.8 \mathrm{~m}$ (scenarios $C$ and $D$ in Fig. 2) appears to be a critical threshold, confirming the earlier-mentioned field observations. Figure 3a shows the correlation between the decrease in total snow depth (starting from a well- insulating $1.2 \mathrm{~m}$ thick snow cover) and the resulting changes in mean annual ground surface temperatures (MAGST). The rate of temperature decrease in the non-linear relationship (exponential decay; $R^{2}>0.999$ ) reflects the thermal resistance effect of a snow cover of varying thickness. Changes in snow depth in a thick snow cover show smaller effects on MAGST than equivalent changes within a thin snow cover. The parameters of the correlation curve are listed in Table 1. Altogether, Figure $3 \mathrm{a}$ indicates that with constant air temperature a snow-depth increase of $1 \mathrm{~m}$, starting with a $0.2 \mathrm{~m}$ thin non-insulating snow cover, raises MAGST by

Table 1. Correlation equations and parameters of the effect of changes in snow depth $(\Delta \mathrm{HS})$, delay in total snowmelt $\left(\Delta t_{\text {melt }}\right)$, delay in first insulation of the snow cover $\left(\Delta t_{\text {snow }}\right)$, and changes in MAAT on changes in MAGST shown in Figure 3

Non-linear correlations $y=a_{1} \exp \left(x / t_{1}\right)+y_{0}$

$X$

$a_{1}$

$t_{1}$

$y_{0}$

$R^{2}$

\begin{tabular}{|c|c|c|c|}
\hline $\begin{array}{l}\Delta \mathrm{HS} \\
\Delta t_{\text {melt }}\end{array}$ & $\begin{aligned}-0.0812 & \pm 0.0118 \\
-0.19995 & \pm 0.04995\end{aligned}$ & $\begin{array}{r}-0.2827 \pm 0.01108 \\
26.44844 \pm 3.36573\end{array}$ & $\begin{array}{l}0.99945 \\
0.99944\end{array}$ \\
\hline \multicolumn{4}{|c|}{ Linear correlations $y=A \pm B x$} \\
\hline$x$ & $A$ & $B$ & $R^{2}$ \\
\hline$\Delta t_{\text {snow }}$ & $0.133 \pm 0.0982$ & $-0.0199 \pm 0.00133$ & 0.9933 \\
\hline$\triangle \mathrm{MAAT}$ & $-0.06 \pm 0.027$ & $0.49 \pm 0.0195$ & 0.9977 \\
\hline
\end{tabular}



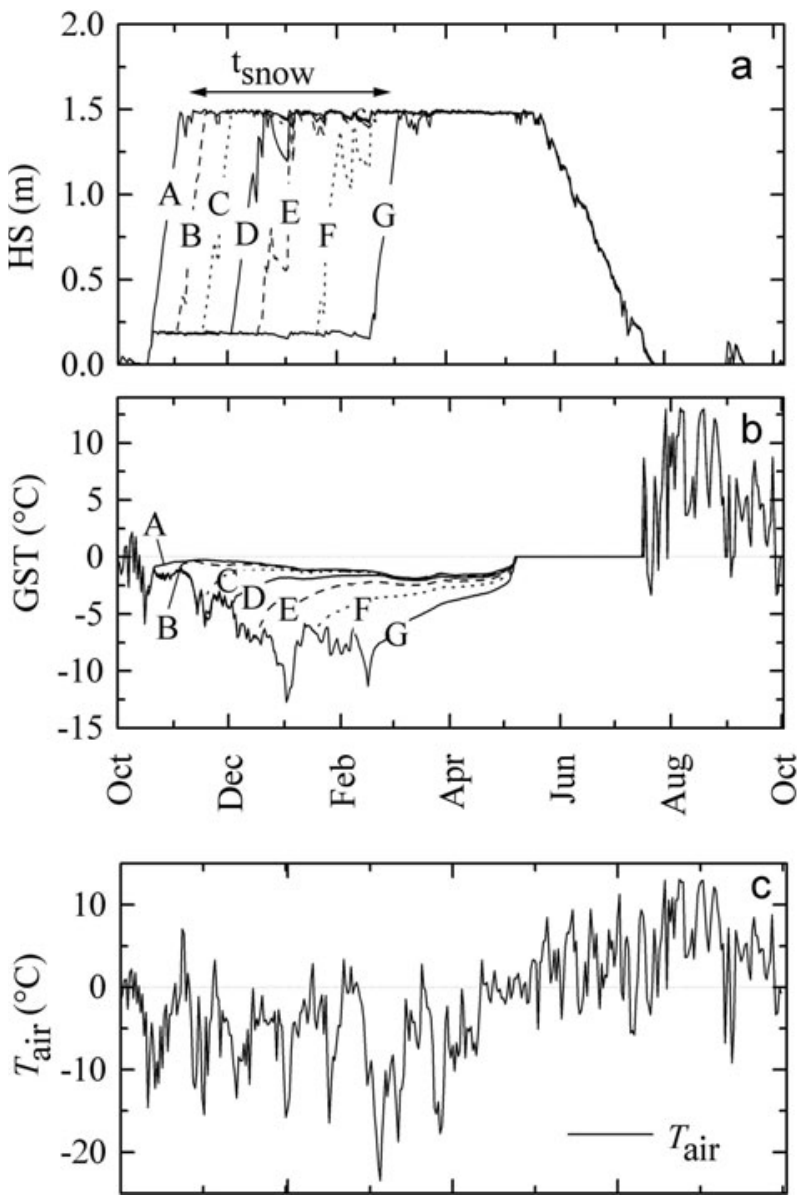

Fig. 4. (a,b) Simulated snow-depth scenarios (HS) for (a) different dates of first important snowfalls in winter and (b) the resulting GST. The extension of the thin-snow cover stage in early winter (first insulation on (A) 18 October, (B) 3 November, (C) 17 November, (D) 3 December, (E) 18 December, (F) 19 January and (G) 18 February) has a cooling effect on ground temperatures. (c) Air temperature $\left(T_{\text {air }}\right)$ remained unchanged $(\mathrm{c})$.

$\sim 2.7^{\circ} \mathrm{C}$. This result compares well with earlier measurements (Haeberli, 1985).

At most high-alpine permafrost sites, the date of first important snowfalls in winter and the onset date of a thick persistent winter snow cover show strong year-to-year variations and complex spatial variations related to topography.

In order to study the effect of a delay in effective thermal resistance of an early-winter snow cover on ground temperatures, five snow-cover scenarios were generated. In these scenarios, snow depths initially exceed $0.6-8 \mathrm{~m}$ (implying a thermal decoupling of the ground from the atmosphere) in (1) mid-October, (2) mid-November, (3) midDecember, (4) mid-January and (5) mid-February. Prior to these dates, early-winter snow cover is $\sim 0.2 \mathrm{~m}$. Simulation results are illustrated in Figure $4 \mathrm{a}-\mathrm{c}$, showing the simulation inputs of the five snow-depth scenarios, the resulting GST and air temperature, respectively. Delayed arrival of the first significant snowfalls in winter causes GST to decrease in response to the low early-winter air temperatures. These lower early-winter GST persist throughout the following snow-insulation stage until the end of winter (Fig. 4). The duration of a thin snow cover in early winter and the MAGST are linearly correlated $\left(R^{2}=0.993\right)$ (Fig. 3a), so that later
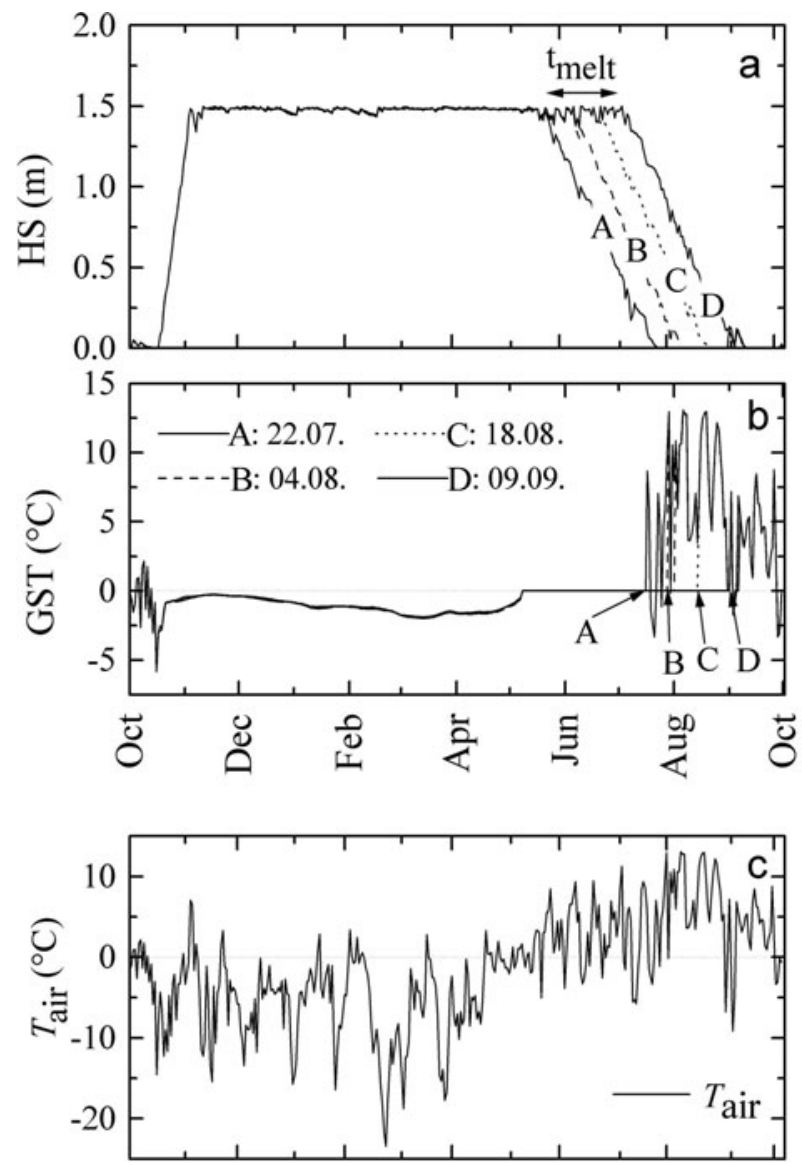

Fig. 5. $(a, b)$ Simulated snow-depth $(\mathrm{HS})$ scenarios for (a) different dates of total snowmelt in spring and (b) the resulting GST. With a total snow meltout delay in summer (total snowmelt on (A) 22 July, (B) 4 August, (C) 18 August and (D) 9 September), the GST show a longer zero-curtain. (c) Air temperature $\left(T_{\text {air }}\right)$ remained unchanged for all simulation runs.

arrival of significant snowfall is associated with a decrease in MAGST values. A 1 month delay in establishing snow depths sufficient to provide effective thermal resistance resulted in a MAGST decrease of $\sim 0.5^{\circ} \mathrm{C}$.

Snow disappearance in spring can show strong temporal and spatial variations due to the year-to-year variations in the climate variables and due to variations related to topography. This is particularly so at the base of steep slopes, where avalanche snow accumulates during the winter. Here, total snow disappearance can be delayed by several weeks, if not months, compared to the slope above (e.g. Haeberli, 1975; Luetschg and others, 2004). The effect of the date of total snowmelt on ground temperatures was studied on the basis of four snow-cover scenarios showing total snow disappearance on 22 July, 4 August, 18 August and 9 September, respectively. In Figure 5, the simulation inputs of total snow depths (Fig. 5a) and the resulting GST (Fig. 5b) are shown together with air temperatures (Fig. 5c). Apart from snowdepth modifications, the other parameters were left unchanged. Delaying snow disappearance results in a longer duration of the snowmelt season, during which GST are close to $0^{\circ} \mathrm{C}$. The correlation between the extension of the snowmelt stage and the MAGST shows an exponential decrease in MAGST as the snowmelt season lengthens (Fig. 3c). In these simulations, a delay in snow disappearance by 1 month was observed to cause a $0.5^{\circ} \mathrm{C}$ lower MAGST. 

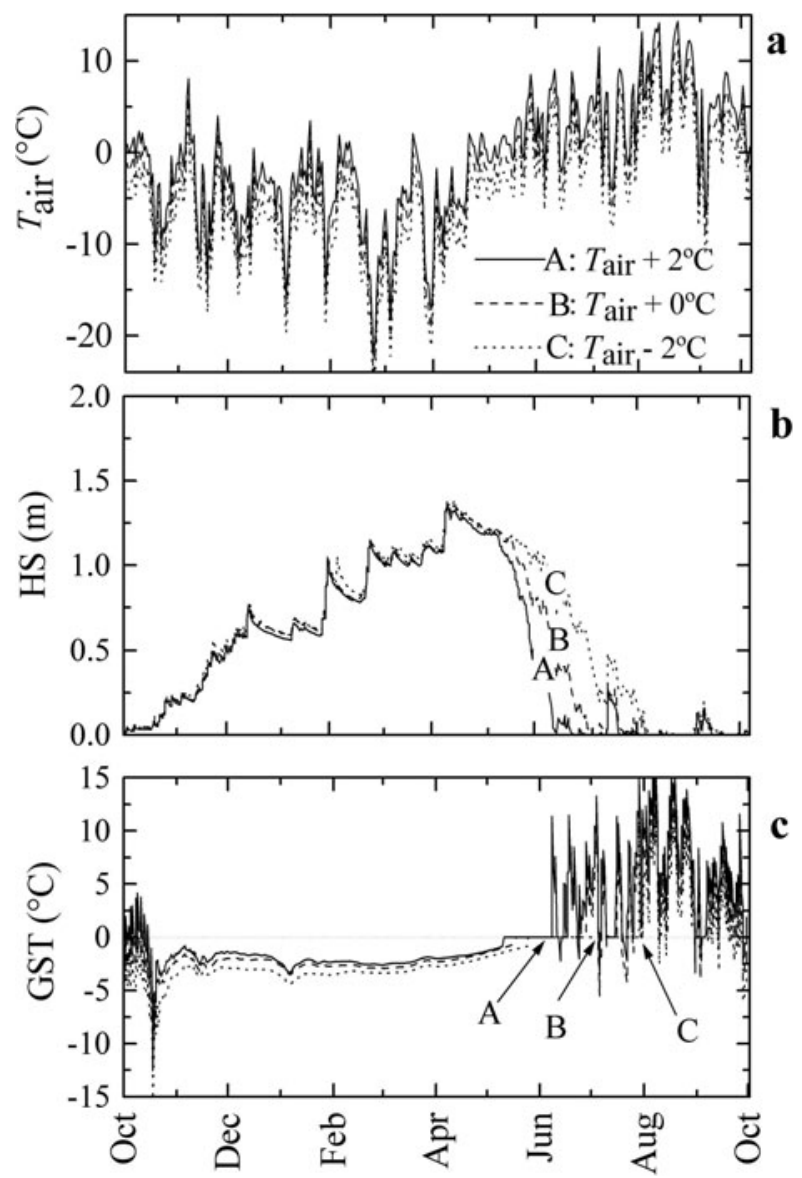

Fig. 6. (a) Simulated air temperature $\left(T_{\text {air }}\right)$ scenarios with MAAT offsets of (A) $0^{\circ} \mathrm{C}$, (B) $-2^{\circ} \mathrm{C}$ and (C) $2^{\circ} \mathrm{C}$. (b, c) The effect on (b) snowdepth evolution (HS) and (c) GST.

The effect of changing mean annual air temperatures (MAAT) on the snow-depth evolution and the underlying GST was investigated. As with the simulations presented above, those in this section were based on the meteorological data record from Weissfluhjoch, 1992/93 but using the water equivalent of the snow cover (from Snow 1, Fig. 1) rather than total snow depth. The input MAAT in the present simulations was varied by an offset of $0,+1,+2,-1$ and $-2^{\circ} \mathrm{C}$. Figure $6 \mathrm{a}-\mathrm{C}$ show the input air-temperature curves with the offset of $0,-2$ and $+2^{\circ} \mathrm{C}$, the resulting individual snow-depth evolutions and GST, respectively, revealing the main influence to be during the snowmelt stage. In contrast to its weak effect on early-winter snow depth, air-temperature change strongly influences the date of complete snowmelt in summer. Snowmelt under the $2{ }^{\circ} \mathrm{C}$ warmer MAAT occurs 11 days earlier but, under a $2^{\circ} \mathrm{C}$ colder MAAT, is delayed by 35 days. Accordingly, under the influence of lower air temperatures and a longer-lasting snow season, GST are lower and show a longer snowmelt infiltration stage with constant zero temperatures compared to the effect of higher air temperatures and hence shorter periods of snow cover. Figure $3 \mathrm{~d}$ shows the strong linear correlation $\left(R^{2}=0.997\right)$ between MAAT and MAGST within these simulation runs, which indicate a ground surface temperature increase of $0.5^{\circ} \mathrm{C}$ resulting from an air-temperature increase of $1^{\circ} \mathrm{C}$. All parameters specifying the correlation curves shown in Figure 3 are listed in Table 1.

The slope of the linear dependency between changes in MAAT and MAGST differs for simulations with different

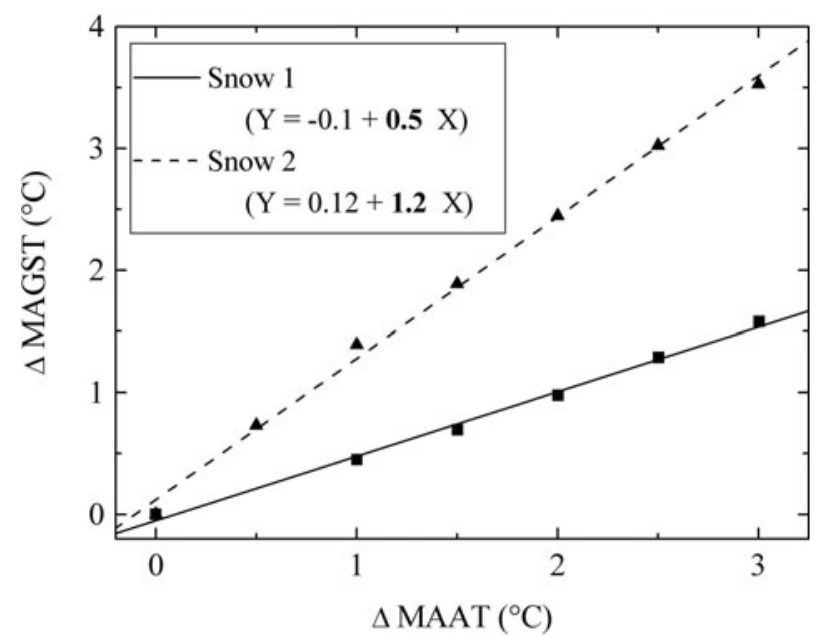

Fig. 7. The linear correlation between $\triangle$ MAAT and $\triangle M A G S T$ shows a steeper regression line for the snow scenario of a thin and late insulating snow cover (Snow 2) compared with the snow scenario of an early insulating and thick snow cover (Snow 1).

meteorological input data. Figure 7 shows the comparison of the linear MAAT-MAGST correlation for the present study, which is based on the meteorological data record 'Weissfluhjoch 1992/93' and the snow-cover input 'Snow 1', and that of an earlier study presented by Luetschg and others (2003), which was based on the data record 'Weissfluhjoch 1993/94' and the snow-cover input 'Snow 2' (Fig. 1). The slope of the earlier Snow 2 study was determined as 1.2, compared to the value of 0.5 observed in the present study (Snow 1). These slopes imply that changes in mean permafrost temperatures are expected to exceed mean airtemperature changes in areas under a thin snow cover, whereas for areas covered by a thick snowpack, air temperature changes exceed changes in ground temperature. This can have a crucial influence on spatial distribution patterns of impacts of changing air temperatures on permafrost temperatures, enhancing changes on steep rock walls and wind-eroded summits/crests, and in arid or subpolar lowlands that generally have a thin snow cover.

Figure $8 \mathrm{a}$ and $\mathrm{b}$ show the significant difference between the snow depth (HS) evolution for the simulation of the present study (Snow 1) and the simulations presented by Luetschg and others (2003) (Snow 2). The Snow 1 simulations are based on a thicker snow cover, which reaches an effective thermal resistance (i.e. snow depths $\sim 0.6-0.8 \mathrm{~m}$ ) in early December and which shows total snow meltout at the end of July. The Snow 2 simulations are based on a very thin snow cover with snow depths almost constantly below $0.6 \mathrm{~m}$ and thus of lower thermal resistance and with an extraordinarily late snow meltout date in mid-September. The resulting GST of the Snow 2 simulations show diurnal fluctuations over a longer period, indicating the influence of air temperature, and under the impact of increasing air temperatures the total snow meltout shows different time shifts for the Snow 1 simulations compared to those of Snow 2.

The snow-cover scenarios in Figure 8 can be divided into different snow stages associated with different ground thermal influences: (A) a thin-snow cover interval in early winter, coupling the air temperatures with ground temperatures, (B) an above-threshold snow-depth interval during which the ground is thermally uncoupled from the cold 


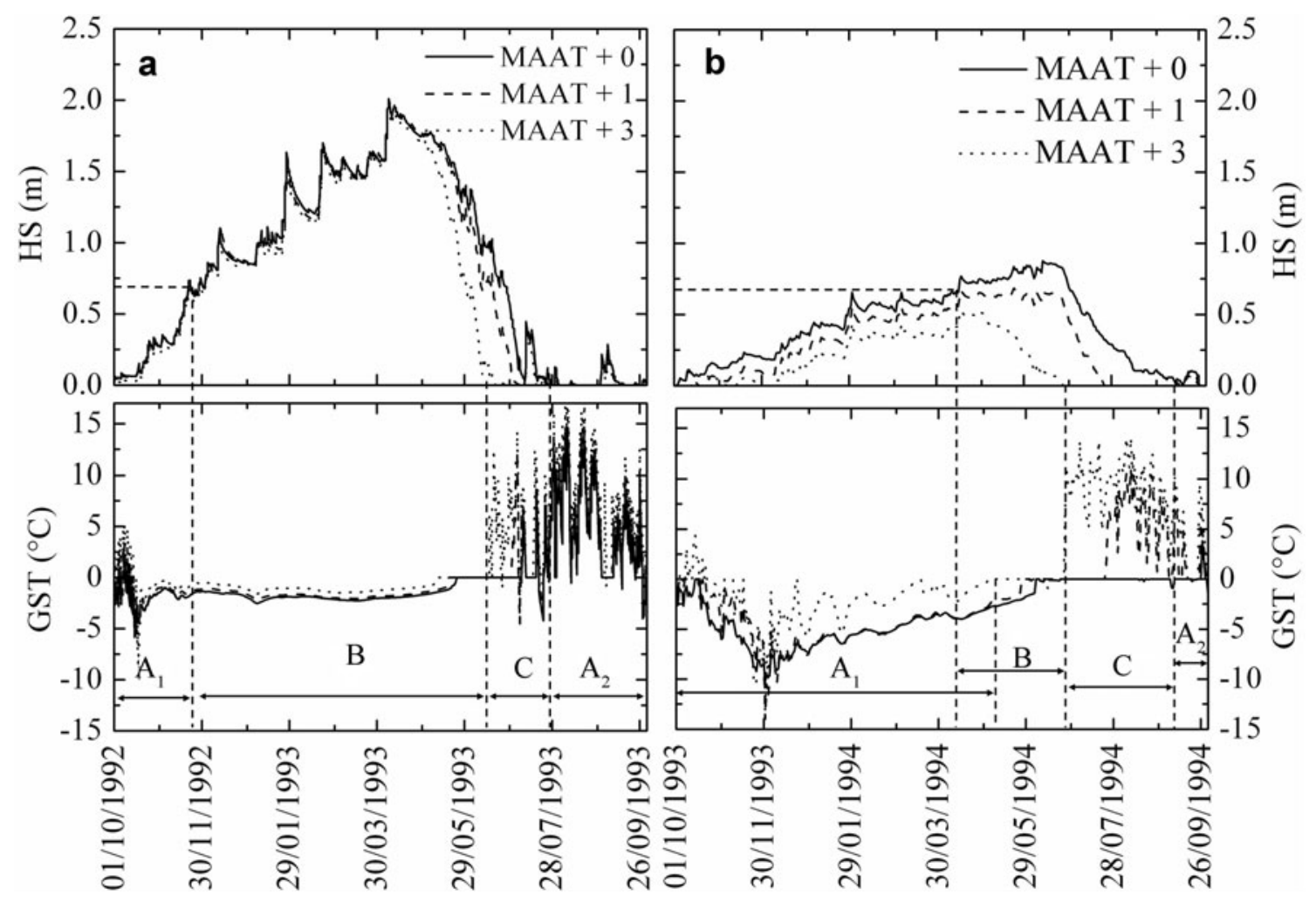

Fig. 8. Snow depth (HS) under the impact of higher MAAT for the two snow-cover scenarios Snow 1 (a) and Snow 2 (b) and the effect on GST. The GST behaviour is characterized by the durations of different stages: $\left(A_{1}\right)$ the early winter thin-snow stage, $\left(A_{2}\right)$ the snow-free stage, $(B)$ the fully insulating snow stage and $(\mathrm{C})$ the range of time shift of total snowmelt due to the increasing MAAT. The durations of each stage are listed in Table 2. Dates are dd/mm/yyyy.

winter atmosphere and (C) a transition interval, which is characterized by the time shift of the snow meltout in spring as a consequence of increasing MAAT. In Figure 8 these periods are shown for both the Snow 1 and the Snow 2 simulations. $A_{1}$ indicates the duration of the period with thin early-winter snow cover of low thermal resistance (in this case $0.6 \mathrm{~m}$ (e.g. Hanson and Hoelzle, 2004)). If snow depths never exceed the threshold value during winter, $\mathrm{A}_{1}$ ends with the start of the snowmelt season indicated by constant zero temperatures in the GST of the warmest temperature scenario $(M A A T+3) . A_{2}$ indicates the duration of the snow-free period in summer, B marks the duration of the above-threshold depth of the snow cover including the snowmelt duration of the warmest scenario and $\mathrm{C}$ indicates the total change in duration of the snow-free period due to the time shift of the date of snow meltout caused by increasing air temperatures within the range of all climate-change scenarios.

The durations of the individual stages are listed in Table 2 for both simulation runs. If, under the impact of higher air temperatures, snow depth never exceeds $0.6 \mathrm{~m}$, as shown in the Snow 2 scenario (Fig. 8b), the durations $A_{1}$ and $B$ for that scenario are confined by the centre of their overlap interval. The duration of the early-winter thin snow covering of the Snow 1 simulations is $\sim 5$ weeks shorter compared to the Snow 2 simulations, and, in turn, the insulating snow cover in mid-winter of the Snow 1 simulations exceeds that of the Snow 2 simulations by 5 weeks.

\section{DISCUSSION}

From the above simulations, the slope of the MAAT-MAGST correlation appears to be controlled by the duration of the snow stages during which the atmosphere and the ground are thermally coupled (Fig. 8). The duration of the thermal coupling of air temperatures and ground temperatures is determined by a combination of snow depth and time of total snowmelt (snow stages $A_{1}$ and $A_{2}$ ). Higher air temperatures result in earlier snow disappearance in summer. The time shift of the snow meltout date under the impact of higher air temperatures (snow stage C) is controlled by a combination of total snow depth, air temperatures and date of snow disappearance in the initial meteorological data record. It is especially large for cases with thin snow. With a much earlier meltout date in summer, the duration of direct exposure of the ground to summer air temperatures is strongly increased. This can result in a MAAT-MAGST regression curve increasing from below to above unity (Fig. 7).

Consequently, the most direct reaction of ground temperatures to increasing air temperatures is expected to be found at steep or windswept locations with a thin snow cover showing relatively early snowmelt in spring and/or large changes in the date of total snowmelt in response to atmospheric warming. However, earlier studies based on SNOWPACK simulations (Luetschg and others, 2003) have shown that the water content of the soil also influences the slope of the MAAT-MAGST correlation. At locations with a thick, long-lasting snow cover, such as the base of steep avalanche slopes, ground temperatures are expected to show a slower reaction to air-temperature change (see Luetschg and others, 2003).

The present sensitivity study shows that the snow cover (i.e. snow depth and duration) plays a major role in MAGST and permafrost distribution. The duration of thin snow cover 
in early winter was shown to be significant as it affects ground temperature evolution during the entire winter. The significance of autumn snow cover affecting ground thermal regime had been observed in previous studies, mostly on the basis of field investigations (e.g. Keller, 1994; Zhang, 2005). In this numerically based study, the effect on ground temperatures of changes in the duration of a thin snow cover in early winter (i.e. snow depth not providing effective thermal resistance) was shown to be of the same order of magnitude as the effect of changes in the date of snow disappearance in spring when keeping all other parameters unchanged. Development of a thermally insulating snow cover 1 month earlier in autumn, and a snow meltout in spring taking place 1 month later, both raised MAGST by $\sim 0.5^{\circ} \mathrm{C}$. The snow-depth influence on ground temperatures in the present sensitivity study (Fig. 3a) confirms earlier estimates derived from field observations (Haeberli, 1985), predicting an increase of $\sim 2^{\circ} \mathrm{C}$ in mean annual permafrost temperature resulting from a snow-depth increase of $1 \mathrm{~m}$ between November and February.

A sensitivity study of the effect of the timing and duration of a seasonal snow cover in arctic permafrost regions by Ling and Zhang (2003) emphasized the important contribution of earlier disappearances of spring snow cover to Arctic warming and permafrost thawing. Evidently, in the arctic permafrost environment, where snow depths are generally much thinner than in the alpine environment, thermal decoupling of the ground thermal regime from the winter atmosphere by a seasonal snow cover plays a minor role, and thus an earlier onset date of the seasonal snow cover shows a smaller influence on MAGST.

In the simulations presented here, a series of artificial snow input datasets was created in terms of timing, duration and total snow depths. These snow-depth scenarios do not represent seasonal snow conditions measured in reality, but nevertheless form the basis for a systematic analysis of individual processes. In the context of the current study, the snow-cover scenarios can be regarded as representing local differences in snow accumulation due, for instance, to snowdrift. This is not to be confused with true climate scenarios, in which a full set of new forcing variables must be used. Rugged alpine terrain leads to a small-scale variability of the snow cover, while meteorological forcing at some height, especially air temperature, radiation and wind, may be similar. Since our sensitivity studies are based on a model, which physically represents the effect of meteorological forcing on snow and soil, they appear to be suitable to identify the influence of snow-cover depth and duration on permafrost for a typical alpine climate. They cannot be interpreted as a climate-change scenario but provide first insights into corresponding sensitivities and governing factors. Simulations of long-term evolutions with various scenarios of climate change require changing the depth and thermal boundary condition at the base of the model and introducing latent heat involved with deep freezing and thawing processes.

\section{CONCLUSIONS}

For the first time, a snow-cover-permafrost interaction model has been developed and adapted for 1-D process studies under high-alpine snow and permafrost conditions, by combining a sophisticated numerical description of a seasonal alpine snow cover with a model of the underlying
Table 2. Individual duration (days) of the early-winter thin-snow stages $\left(A_{1}\right)$, the snow-free stages $\left(A_{2}\right)$, the fully-insulating snow stages (B) and the time shifts of total snowmelt due to the increasing MAAT (C) for the two snow-cover scenarios shown in Figure 8

\begin{tabular}{lcc}
\hline & $\begin{array}{c}\text { Snow } 1 \text { duration } \\
\text { days }\end{array}$ & Snow 2 duration \\
& & days \\
\hline$A_{1}$ & 49 & $172-214$ \\
$A_{2}$ & 68 & 5 \\
$B$ & 213 & $95-53$ \\
$C$ & 35 & 93 \\
\hline
\end{tabular}

ground. From the model-based sensitivity study of the snowcover-permafrost interactions in a high-alpine environment, the following conclusions may be drawn:

1. The thermal resistance of the snow cover was confirmed to increase with increasing snow depth. Within the simulations, effective thermal resistance was observed with snow depths more than $0.6-0.8 \mathrm{~m}$, which is in agreement with the value of $0.8 \mathrm{~m}$ determined from field measurements on a coarse blocky ground surface by Keller and Gubler (1993) and commonly used with the 'bottom temperature of the snow cover' (BTS) method for rapid permafrost mapping in wintertime (Haeberli 1973).

2. The date of first significant snowfalls in autumn strongly affects ground temperatures. The longer the noninsulating snow period during which the cold winter atmospheric temperatures affect ground temperatures, the colder are the GST during the entire year.

3. Comparing the effect of all parameters considered in this sensitivity study, snow-depth variations in a generally thin snow cover (i.e. snow depths less than $0.6 \mathrm{~m}$ ) had the strongest thermal influence on permafrost, followed by the effect of the date of first snow insulation and the MAAT. The snow-depth impact on ground temperatures can be described by fitting a curve of exponential decay, whereas the air temperatures have a linear influence on ground temperatures.

4. The linear dependency of the MAAT-MAGST correlation established different slopes for different meteorological input data, which are supposed to be related to different durations of the non-insulating snow periods in early winter and summer and different time shifts of the date of total snow disappearance under the impact of increasing air temperatures: with increasing durations of these periods the slope of the MAAT-MAGST correlation increases from below to above unity.

5. The effect of changes in the non-insulating snow period in early winter on ground temperatures is of the same order of magnitude as the effect of changes in the date of total snowmelt in spring.

6. This sensitivity study provides the first model-based insights into the relative importance of governing factors within the atmosphere-snow-cover-ground system under high-alpine soil and snow conditions. For future investigations of long-term ground thermal evolution, including various scenarios of climate change, further model 
adaptations will be required in simulation depth and thermal boundary conditions at the base of the model.

\section{ACKNOWLEDGEMENTS}

We thank C. Fierz for assistance with the numerical modelling and for helpful discussions, and C. Harris for helpful comments. Constructive reviews by $\mathrm{O}$. Humlum and an anonymous reviewer are acknowledged. This study was partly funded by the Swiss National Science Foundation.

\section{REFERENCES}

Bartelt, P. and M. Lehning. 2002. A physical SNOWPACK model for the Swiss avalanche warning. Part I: numerical model. Cold Reg. Sci. Technol., 35(3), 123-145.

Beniston, M. 1997. Variations of snow depth and duration in the Swiss Alps over the last 50 years: links to changes in large-scale climatic forcings. Climatic Change, 36(3-4), 281-300.

Etzelmüller, B. and 8 others. 2001. Mapping and modelling the occurrence and distribution of mountain permafrost. Nor. Geogr. Tidsskr., 55(4), 186-194.

Fierz, C. and M. Lehning. 2001. Assessment of the microstructure based snow-cover model SNOWPACK: thermal and mechanical properties. Cold Reg. Sci. Technol., 33(2-3), 123-132.

Gauer, P. 1999. Blowing and drifting snow in Alpine terrain: a physically-based numerical model and related field measurements. (PhD thesis, Swiss Federal Institute of Technology.)

Goodrich, L.E. 1982. The influence of snow cover on the ground thermal regime. Can. Geotech. J., 19(4), 421-432.

Haeberli, W. 1973. Die Basis-Temperatur der winterlichen Schneedecke als möglicher Indikator für die Verbreitung von Permafrost in den Alpen. Z. Gletscherkd. Glazialgeol., 9(1-2), 221-227.

Haeberli, W. 1975. Untersuchungen zur Verbreitung von Permafrost zwischen Flüelapass und Piz Grialetsch (Graubünden). Mitt. VAW/ETH 17.

Haeberli, W. 1985. Creep of mountain permafrost: internal structure and flow of Alpine rock glaciers. Mitt. VAW/ETH 77.

Hanson, S. and M. Hoelzle. 2004. The thermal regime of the active layer at the Murtèl rock glacier based on data from 2002. Permafrost Periglac. Process., 15(3), 273-282.

Harris, S.A. and A.E. Corte. 1992. Interactions and relations between mountain permafrost, glaciers, snow and water. Permafrost Periglac. Process., 3(2), 103-110.

Keller, F. and H. Gubler. 1993. Interaction between snow cover and high mountain permafrost, Murtèl-Corvatsch, Swiss Alps. In Cheng, G., ed. Proceedings of the Sixth International Conference on Permafrost, 5-9 July 1993, Beijing, China. Guangzhou, South China University of Technology Press, 332-337.

Keller, F. 1994. Interaktionen zwischen Schnee und Permafrost: eine Grundlagenstudie im Oberengadin. Mitt. VAW/ETH 127.

Laternser, M. and M. Schneebeli. 2003. Long-term snow climate trends of the Swiss Alps (1931-99). Int. J. Climatol., 23(7), 733-750.

Lehning, M., P. Bartelt, B. Brown, T. Russi, U. Stöckli and M. Zimmerli. 1999. SNOWPACK model calculations for avalanche warning based upon a new network of weather and snow stations. Cold Reg. Sci. Technol., 30(1-3), 145-157.
Lehning, M., P. Bartelt, B. Brown, C. Fierz and P. Satyawali. 2002a. A physical SNOWPACK model for the Swiss avalanche warning. Part II: snow microstructure. Cold Reg. Sci. Technol., 35(3), 147-167.

Lehning, M., P. Bartelt, B. Brown and C. Fierz. 2002b. A physical SNOWPACK model for the Swiss avalanche warning. Part III: meteorological forcing, thin layer formation and evaluation. Cold Reg. Sci. Technol., 35(3), 169-184.

Lehning, M., H. Löwe, M. Ryser and N. Radeschall. In press. Inhomogeneous precipitation distribution and snow transport in steep terrain. Water Resour. Res.

Ling, F. and T. Zhang. 2003. Impact of the timing and duration of seasonal snow cover on the active layer and permafrost in the Alaskan Arctic. Permafrost Periglac. Process., 14(2), 141-150.

Ling, F. and T. Zhang. 2004. A numerical model for surface energy balance and thermal regime of the active layer and permafrost containing unfrozen water. Cold Reg. Sci. Technol., 38(1), 1-15.

Ling, F. and T. Zhang. 2006. Sensitivity of ground thermal regime and surface energy fluxes to tundra snow density in northern Alaska. Cold Reg. Sci. Technol., 44(2), 121-130.

Luetschg, M., P. Bartelt, M. Lehning, V. Stoeckli and W. Haeberli. 2003. Numerical simulation of the interaction processes between snow cover and alpine permafrost. In Proceedings of the Eighth International Conference on Permafrost, 21-25 July 2003, Zurich, Switzwerland. Lisse, A.A. Balkema, 697-702.

Luetschg, M., V. Stoeckli, M. Lehning, W. Haeberli and W. Ammann. 2004. Temperatures in two boreholes at Flüela Pass, Eastern Swiss Alps: the effect of snow redistribution on permafrost distribution patterns in high mountain areas. Permafrost Periglac. Process., 15(3), 283-297.

Lütschg, M. 2005. A model and field analysis of the interaction between snow cover and alpine permafrost. (PhD thesis, University of Zürich.)

Mellor, M. 1977. Engineering properties of snow. J. Glaciol., 19(81), 15-66.

Romanovsky, V.E., T.E. Osterkamp and N.S. Duxbury 1997. An evaluation of three numerical models used in simulations of the active layer and permafrost temperature regimes. Cold Reg. Sci. Technol., 26(3), 195-203.

Seppälä, M. 1994 Snow depth controls palsa growth. Permafrost Periglac. Process., 5(4), 283-288.

Smith, M.W. and D.W. Riseborough. 1996. Permafrost monitoring and detection of climate change. Permafrost Periglac. Process., 7(4), 301-309.

Sturm, M., J. Holmgren, M. König and K. Morris. 1997. The thermal conductivity of seasonal snow. J. Glaciol., 43(143), 26-41.

Zhang, T. 2005. Influence of the seasonal snow cover on the ground thermal regime: an overview. Rev. Geophys., 43(4), RG4002. (10.1029/2004RG000157.

Zhang, T. and K. Stamnes. 1998. Impact of climatic factors on the active layer and permafrost at Barrow, Alaska. Permafrost Periglac. Process., 9(3), 229-246.

Zhang, T., T.E. Osterkamp and K. Stamnes. 1996. Influence of the depth hoar layer of the seasonal snow cover on the ground thermal regime. Water Resour. Res., 32(7), 2075-2086.

Zhang, T., T.E. Osterkamp and K. Stamnes. 1997. Effects of climate on the active layer and permafrost on the North Slope of Alaska, USA. Permafrost Periglac. Process., 8(1), 45-67.

Zhang, T., R.G. Barry and W. Haeberli. 2001. Numerical simulations of the influence of the seasonal snow cover on the occurrence of permafrost at high latitudes. Nor. Geogr. Tidsskr., 55(4), 261-266.) 